\title{
REFUGEE AND LAND DISPUTE \\ (A Case Study at Gamsungi and Tosoa Villages, South lbu District, Regency of West Halmahera, Year 2015)
}

\author{
Bakri La Suhu ${ }^{1}$, Marno Wance ${ }^{2}$, Ikram Hasan ${ }^{3}$ \\ ${ }^{1}$ Lecture of Governmental Science Department, Univrsitas Muhammadiyah Maluku Utara \\ ${ }^{2}$ Lecture of Governmental Science Department, Univrsitas Muhammadiyah Maluku Utara \\ ${ }^{3}$ Lecture of Governmental Science Department, Univrsitas Muhammadiyah Maluku Utara \\ bakrilasuhu@yahoo.co.id ${ }^{1}, \underline{\text { ipmummu@gmail.com }}{ }^{2}, \underline{\text { ipmummu@gmail91.com }}{ }^{3}$ \\ DOI: https://doi.org/10.18196/jgpp.61108
}

\section{Article Info}

Article history:

Received 31 Okt 2018

Revised 17 Nov 2018

Accepted 30 Nov 2018
Keywords : Conflict, Land Dispute,

\begin{abstract}
This study aims at figuring out the causes of land disputes and the settlement between Gamsungi and Tosoa villagers in South Ibu District of West Halmahera Regency. This study applies qualitative descriptive method in which it is a series of procedures used in solving the problems being investigated by describing the state of research objects at present time based on existing facts. The data sources used are primary and secondary data. While the technique of data collections are observation, document interview and secondary data aid. The results show that the causes of land dispute between Gamsungi and Tosoa villages due to: a). The arrival of ex-refugees from Lata-lata village in South Halmahera regency, b). Land expropriation and/ or land disposal by ex-refugees of Lata-lata village to the agricultural field of Gamsungi villagers, and c). Felling of plants in the agricultural field of Gamsungi villagers done by Lata-lata refugees. Therefore, the mechanism or way of settling land disputes between these two villages is through negotiation (consensus). Negotiations were done between the two villages' representatives (Gamsungi and Tosoa villages): the two villages' heads, secretaries, customary figures, religious leaders, and heads of BPD, and witnessed by Subdistric Head of South Ibu, Head of Criminal Investigation Unit of West Halmahera, Representatives of West Halmahera Government, Police Chief of Ibu, Sambung Rasa Team, and Koramil of Ibu.
\end{abstract}

\section{INTRODUCTION}

Land has a meaning and very important role for human life, because for living most people need land. In Indonesia, land is not just a place where people live in but it is their identity. Besides, as a country with an agrarian system, to Indonesian people, land is a very useful to reach various fields, in which the land itself is also a basic capital in development and benefits that can be cultivated as well.

Land has a big role in the dynamics of the country development. Therefore, in the 1945 Constitution article 33 paragraph 3, it is mentioned that "the earth, the inland water and the natural resources contained therein are controlled by the state 
64 and calculated for the greatest prosperity of the people". Law about land can also be found in Law of Republic of Indonesia Number 5 of 1960 concerning Basic Regulations on Agrarian Principles or what we commonly call the UUPA. The emergence of legal disputes originates from complaints of a party (a person / an institution) that contain words of the right towards the land, either on the status of the land and the priorities, or on the holders' hope for legal disputes to be admnistrasively solved in accordance with the applicable provisions.

For majority of humans, holding land is like eating rice or food or in other word it is a necessity. Holding land connects to self-esteem (social value), income (economic value), power and privileges (political value), and a place to worship the Creator (sacred-cultural value). Having no land means losing self-esteem, strength, and a place of contact between humans and the Creator. By natural, everyone struggles to own land and defend it. The struggle is issued by totality in keeping the land to death because having no land means losing self-esteem and privilage (Nurhasan Ismail, 2011).

Land, for humans, contains a multidemensional meaning. Firstly, from an economic standpoint, land is a means of production that can bring prosperity. Secondly, politically, land can determine one's position in community decisionmaking. Thirdly, as cultural capital, it can determine the high and low social status of the owner. Fourthly, the sacred ground, because at the end of life everyone will return to the land. Because of the multidimensional meaning that there is a tendency that people who own land will defend their land in any way if their rights are violated (Heru Nugroho, 2001: 237).

Land disputes occur in many regions in Indonesia and increase casualties, as well as property losses. The root of the land disputes is land use claimed by the community to have been controlled for years or illegal exploration of natural resources which damages the society's trust. Disputes can occur because there is no meeting point among parties in disputed land use. Considering the losses, the payment problem must be solved quickly. As that which occurs in the land dispute case between Gamsungi and Tosoa villagers. 
At first the villagers of Gamsungi and Tosoa walked in harmony and peace, even in social life mutual cooperation between the two villages was very tight. The people of Tosoa village established a Church that was used as a place of worship, the process of establishing the Church was not separated from the spirit of mutual cooperation between the two villages. In building the Church with the help of Gamsungi villagers, the two villages agreed to sign an agreement in which some land of the Tosoa villagers would be carried out and used as plantation area by the Gambungi villagers. The agreement went well and the construction of the Church was finished as it was planned.

The land dispute occurred between the Gamsungi and Tosoa villages began with the arrival of ex-refugees from Lata-lata village to Tosoa, which then tried to incite the Tosoa villagers to take back the land that had been planted by the Gamsungi villagers. Ex-refugee from Lata-lata's brutal action on behalf of Tosoa villagers was happened on January 26, 2012. They destroyed or cut down several kinds of plants of Gamsungi villagers, namely:

(1) 154 coconut trees / 11 owners,

(2) 39 nutmeg trees / 6 owners,

(3) 15 cocoa trees / 1 owner,

(4) Burning 5 garden houses, and

(5) Burning 3 pieces of para-para (a spot for roasting raw).

Economically, the material losses of the damage were calculated for about $\mathrm{Rp}$. 759,500,000,.. with the details: (1) 154 coconut trees@3,000,000 to Rp. 462,000,000, (2) 39 nutmeg trees @5,000,000 to Rp. 195,000,000, (3) 15 cocoa trees @2,500,000 to Rp. 37,500,000, (4) 5 garden houses @10,000,000 to Rp. 50,000,000, and (5) 3 parapara@5,000,000 to Rp. 15,000,000. Reactingon the brutal action, the Gamsungi villagers made various legal efforts (reporting to the authorities) to be able to maintain the land that had been managed for a long time.

\section{RESEARCH METHOD}

\section{Research Type}

This research uses qualitative descriptive type which can be understood as a series of procedures used in solving problems that are investigated/ investigated by describing the present state of the objects based on the facts. 


\section{Data Sources}

Primary data are data taken based on the results of observations and interviews which are the main sources in this study. The data collected through informants are as follows: (a) Secretary of the Head of the South Ibu District, (b) Head of Gamsungi Village, South Ibu District, (c) Head of Tosoa Village, South Ibu District, (d) Secretary of Gamsungi Village, (e) Secretary of Tosoa Village, (f) The Koramil of Ibu Distric, and (g) Gamsungi Youth Leader.

Secondary data are supporting data obtained based on the results of tracing the rules regarding land disputes, supporting books, journals, documents relating to the research focus.

\section{Data Collection Technique}

Technique of collecting data for this research is conducted through;

(1). Obsevation,

(2). Interview, and

(3). Documentation.

\section{Data Analysis Technique}

In analysing the data, there are three techniques to use, namely:

1. Selecting data/ data reduction,

2. Presenting data/ data display, and

3. Conclusion / data verification.

\section{LITERATURE REVIEW}

\section{Theory of Conclict}

The term conflict in political science is often associated with violence, such as riots, coups, terrorism and revolution. Conflict contains the meaning of "collision", such as differences of opinion, competition, and conflict between individual and individual, group and group, individuals and group, and between groups or individuals with the government (Ramlan Surbakti, 2007: 149).

Conflict is any form of interaction that is opposition or an antagonistic interaction (opposite, contradictory or opposite). Conflict occurs because of differences or scarcity of social position and position of resources or due to extreme 
different value and valuation systems. Conflict can also be interpreted as a clash of power and interests between one group and another in the relatively limited process of fighting for social resources (economic, political, social, cultural). The main source of conflict in society is the existence of social injustice, discrimination against the rights of individuals and or groups of people, and the absence of respect for diversity.

Conflict is a conflict between two or more different positions experienced by a person (internal conflict regarding the motives, desires, efforts, and ethical values) or that occurs between several parties or between groups, countries and other communities (Peter Schroder. 2003: 359).

The definition above is in line with the opinion expressed by R.W. Mack, R.C. Synder and Ted Robert Gurr, that a disagreement can be called a conflict. First, a conflict must involve two or more parties in it. Second, the parties are mutually attractive in mutually opposing actions. Third, they usually tend to carry out coercive behavior to confront and destroy the "enemy". Fourth, the interaction of contradictions between parties is in a firm state, therefore the existence of contradictory events can be easily detected and agreed upon by observers who are not involved in the conflict (Gurr, Robert, Ted, 1980: 2).

\section{Definition of Land Dispute}

According to Ali Achmad (2003: 14), dispute is a conflict between two or more parties that originates from a different perception of an interest or property that can cause legal consequences for both.

According to Rusmadi Murad in Heru Nugroho (2001: 250), the notion of land disputes or can also be said to be a dispute over land rights, that is the emergence of a legal dispute originated from a complaint of a party (person or entity) containing objections and demands for rights to land, both on land status, priority, and ownership in the hope of obtaining an administrative settlement in accordance with the provisions of the applicable regulations.

The definition of land dispute is formulated in Article 1 of the Regulation of the Minister of Agrarian Affairs/ Head of the National Land Agency No. 1 of 1999 
concerning Procedures for Land Dispute Handling, hereinafter referred to as PMNA / KBPN 1/1999, namely:

"Differences of opinion between interested parties regarding the validity of a right, granting land rights, registration of land rights, including the transfer and issuance of proof of rights as well as interested parties who feel they have a legal relationship and other interested parties are affected by the legal status of the land. "

Sociologically, land disputes that occur in the community, apart from being caused by the above matters can also be caused by several things:

1. Misunderstanding due to communication failure

2. Differences in purpose and value of life

3. Scramble, rivalry in limited matters

4. Lack of cooperation, which results in disappointment and feelings of loss

5. Not obeying or obeying the rules and regulations that exist in society or the State

6. There is an attempt to control and harm certain parties so that the aggrieved party holds resistance (BPN RI, 2007: 6)

According to Sarjita (2005: 8), land disputes are: "disputes that occur between two or more parties who feel or are harmed by those parties for the use and control of their land rights, which are resolved through deliberation or through a court." Rusmadi Murad (1991: 23) states that the nature of the problem of a dispute is found in several types:

1. Problems concerning priority to be able to be established as legal right holders of land with land rights that have no rights.

2. Denial of the right / proof of acquisition used as the basis for granting rights.

3. Errors / errors in granting rights due to less application / incorrect regulations.

4. Other disputes / problems that contain practical and social aspects (strategic).

\section{Settlement of Land Dispute}

In general, land dispute resolution can be resolved through non-litigation and litigation channels. Through litigation, it is carried out through the judiciary, while 
through non-litigation channels can be pursued through negotiation, conciliation, mediation and arbitration (Mukhsin, 2007: 1).

But in practice that often happens is the pattern of land dispute resolution through non-litigation channels carried out by the Government either preceded by deliberation or directly handled based on the existing authority, which in its implementation always considers various aspects of socio-economic and not infrequently pursued by political approaches, especially through Government policies. This means that the land issue is attempted to be resolved by the Government in a compromise manner by accommodating various interests both through mediation efforts and through the issuance of policies.

The authority to settle land disputes is carried out by the National Land Agency agency through its main duties and functions as expressly stipulated in Presidential Decree Number 26 of 1988 concerning the National Land Agency in its consideration, among others stated that with increasing needs, control and use of land, especially for development purposes and also increasing problems arising in the field of land, so to solve the problems in the land sector thoroughly, it was deemed necessary to review the position, duties and functions of the Directorate General of Agrarian Affairs of the Ministry of Home Affairs and improve it to become an institution that handles the land sector nationally.

\section{FINDINGS AND DISCUSSIONS}

\section{Causes of Land Dispute Between Gamsungi and Tosoa Villages}

Agrarian problems often cause various frictions and even conflicts between one community to other community, the community with private sector, and even the community with the government. Of course, agrarian problems stem from various triggers that can lead to disputes and or conflicts. According to Juni Thamrin (2001), the trigger source land conflict cases subsequently emerged as a form of disputes in various regions in Indonesia can be identified in the following categories:

a. Problems related to farm land, among others:

a) An unfinished compensation process accompanied by intimidation acts; 
b) Take over of the people's land which has been managed for more than 20 years for farm land;

c) Wide differences in the results of measurements with HGU owned by the farm;

d) The farm are located on ulayat land or clan or inherited land,

b. Problems of requesting land rights relating to foresty area claims, especially those that have not physically functioned as forests again,

c. Disputes over court decisions include:

a) The court decision is not received by the disputing party;

b) Court decisions that cannot be executed because their ownerships status have changed;

c) The Court's decision creates different legal consequences for the status of the same object;

d) the existence of a specific application based on a court decision that does not have permanent legal force,

d. Land border dispute and land registration issues as well as overlapping certificates on the same land,

e. Recklaiming and land occupation issues that have been acquired by housing developers due to manipulated compensation,

f. Land issues over claims of ulayat/ clan land.

g. Problems related to the mechanism for exchanging land, especially crooked land that becomes the village's land.

Land disputes between Gamsungi Village and Tosoa Village could not be separated from the various problems that occurred between the two villages. The cause were due to:

a. The arrival of ex-refugees from Lata-lata village in South Halmahera regency,

b. Land expropriation and/ or land disposal by ex-refugees of Lata-lata village to the agricultural field of Gamsungi villagers, and

c. Felling of plants in the agricultural field of Gamsungi villagers done by Lata-lata refugees. 


\section{Land Dispute Settlement between Gamsungi Village and Tosoa Village}

Disputes are universal legal phenomena that can occur anywhere and at any time, because the dispute is not bound by time and space. Each dispute requires a resolution and there is no dispute without resolution. In connection with resolving conflicts and land disputes in indigenous communities, there are almost the same things in every indigenous community in the archipelago, even though there are few differences here.

Basically, every land dispute case must be resolved through a judicial institution, so it is natural that the LoGA does not discuss land dispute cases, because it is expected to be resolved through the existing judiciary. But in reality, not all land dispute cases that occur can be brought to the judiciary either because of lack of evidence or because the parties are not willing to file a lawsuit to the court or report to law enforcement officials for every land dispute case. With various considerations, the parties are more choosing to be resolved through consensus (negotiation).

Settlement of conflicts and disputes in the condition of community that is still modest, where kinship and group relations are still strong, then the choice of institutions to resolve occure disputes or conflicts is directed to populist institutions, because the institution of traditional dispute resolution or conflict means as an institution guarding order and the return of magical balance in society. Whereas conflicts or disputes that occur in modern society, where social relations are more individualistic and oriented to the market economy, tend to be resolved through dispute settlement institutions that refer to legalistic state law.

Settlement of land conflict by negotiation is carried out by the parties to the dispute to get an agreement for both parties in a win-win solution where no party feels aggrieved. Settlement of land disputes between Gamsungi Village and Tosoa Village was in consultation and consensus with various agreements that had been determined and carried out by both parties to resolve the dispute.

In the settlement of disputes, it also involved the involved parties and had authority in the process of resolving land disputes and witnessed by the two village heads (Gamsungi and Tosoa), the two secretaries of the villages, clan leaders, religious 
12 leaders, and the chairman of the BPD, and witnessed by the Head of the South Ibu distric, Head of Criminal Investigation Unit of West Halmahera Police, Head of Government Office of West Halmahera Regent, Head police of Ibu distric, Team of the Rasa Sambung, and Ibu Koramil.

The form of negotiations (consensus) between the two villages produced several collective agreements. Minutes of agreement agreed between the two villages include:

1. We, residents of Tosoa Village and residents of Gamsungi Village agree to mutually disperse the land that has been processed by each party.

2. The two villages together with the sub-district government go to the location to carry out the data collection.

3. Losses from both parties are borne by the district government evidenced by a written statement from the district government.

4. The district government is obliged to issue land certificates for both parties.

5. Both parties call on the regional government to expedite compensation and issue land certificates.

6. Both parties agree that the report at the West Halmahera District Police will be revoked today.

7. Both parties agree that today, Wednesday 15 February 2012 Gamsungi residents are allowed to process the land forever.

8. If there are problems or things that are not desirable in the future, it is the responsibility of each party.

9. For the reclamation of new agricultural field by both the Gamsungi villagers and other villagers must be known by the Tosoa villagers.

In general, patterns of land dispute/ conflict resolution conducted by the community are as follows: negotiation; deliberation; and mediation. Negotiations are carried out by means of which the conflicting parties sit together to find the best way to resolve the conflict with the principle that the settlement is a win-win solusion, neither side feels harmed. Deliberations are a further step from negotiations. If in the negotiation there is no mutually beneficial agreement, then a further step is to make 
consensus based on the deliberations involving other parties as mediators. These other parties can be family members, religious leaders or clan leaders, even village officials.

\section{CONCLUSIONS}

1. The causes of land dispute between Gamsungi and Tosoa villages due to:

a) The arrival of ex-refugees from Lata-lata village in South Halmahera regency,

b) Land expropriation and/ or land disposal by ex-refugees of Lata-lata village to the agricultural field of Gamsungi villagers, and

c) Felling of plants in the agricultural field of Gamsungi villagers done by Lata-lata refugees.

2. Mechanisms or ways of resolving land disputes between the two villages through negotiations (consensus). Negotiations took place between the two villages with representatives between the two (Gamsungi and Tosoa villages), namely: the two village heads (Gamsungi and Tosoa), the two secretaries of the villages, clan leaders, religious leaders, and the chairman of the BPD, and witnessed by the Head of the South Ibu distric, Head of Criminal Investigation Unit of West Halmahera Police, Head of Government Office of West Halmahera Regent, Head police of Ibu distric, Team of the Rasa Sambung, and Ibu Koramil.

\section{REFERENCES}

Chomzah Ali. Achmad, Seri Hukum Pertanahan III Penyelesaian Sengketa Hak Atas Tanah dan Seri Hukum Pertanahan IV Pengadaan Tanah Instansi Pemerintah, (Jakarta : Prestasi Pustaka, 2003).

Ismail Nurhasan, "Arah Politik Hukum Pertanahan dan Perlindungan Kepemilikan Tanah Masyarakat", Makalah disampaikan pada Acara Seminar tentang Penyelesaian Sengketa dan Konflik Pertanahan Dalam Perspektif Pembaharuan Hukum Pertanahan Nasional, yang diselenggarakan Badan Pembinaan Hukdan HAM pada tanggal 17 Nopember 2011 di Bandung.

Mukhsin, Aspek Hukum Sengketa Hak Atas Tanah, makalah disampaikan pada Workshop Strategi Penanganan dan Penyelesaian Sengketa Pertanahan yang diselenggarakan Badan Pertanahan Nasional RI tanggal 19-21 November 2007 di Batam.

Murad Rusmadi, Penyelesaian Sengketa Hukum Atas Tanah, Alumni, Bandung, 1991.

Nugroho Heru, Menggugat Kekuasaan Negara, (Surakarta: Muhammadiyah University Press 2001).

Peter Schroder, 2003. Strategi Politik. Penerbit: Friedrich-Naumann-Stiftung, Jakarta 
Robert, Ted Gurr, 1980. Hand Book of Political Conflict : Theory and Research (New York : The Free Press)

Ramlan Surbakti, 2007. Memahami Ilmu Politik. Gramedia Widia Sarana Indonesia, Jakarta

Sarjita, Teknik dan Strategi Penyelesaian Sengketa Pertanahan, Tugujogja Pustaka, Yogyakarta, 2005. 